\title{
The Role of Academics, Users, and Customers in Industrial Product Development
}

\author{
Leena Kunttu, Yrjö Neuvo
}

\author{
" Not all smart people in the world work for us. We need to work with smart people inside and \\ outside our company."
}

Henry Chesbrough (2003)

\begin{abstract}
Industrial research and development (R\&D) is often adopted as a leading strategy for innovation in high-technology firms. It has been recognized that collaboration with external actors has become increasingly crucial for $R \& D$ practices in a world where product and service innovation are increasingly challenging for companies involved in knowledge-intensive technology areas. Thus, high-technology firms are increasingly engaging in collaborative relationships with external stakeholders to transfer valuable new knowledge for industrial purposes, or to create new knowledge through a joint learning process. These external stakeholders may include research institutes such as universities, customer firms, or end users of the firm's products or services. Academic involvement in industrial innovation projects has traditionally focussed on the early stages of a product's development process, when new ideas and innovations are being developed. On the other hand, the interaction between a firm and its customers takes place during the final stages of the R\&D process, when innovations are brought to market. In this paper, we explore how users and customers can be involved in university-industry collaboration projects from the beginning of the product development process. Based on a case study comprising five long-term university-industry collaborations in Finland, this paper presents collaborative practices through which academic actors, users, and industrial customers may actively take part in the industrial innovation processes.
\end{abstract}

\section{Introduction}

Following the principles of open innovation (Chesbrough, 2003; Enkel et al., 2009; West et al., 2014), high-technology firms are continuously augmenting their research and development $(\mathrm{R} \& \mathrm{D})$ capabilities with external players that are able to provide them with valuable knowledge, competences, and capabilities. This is particularly true for industrial actors operating in the knowledge-intensive technology areas, such as the information and communications technology (ICT) sector (Bellini et al., 2018). Indeed, there are a number of reasons to involve external partners in industrial $R \& D$ processes, including the existence of rapid technological changes, strong markets and competition, the complex nature of innovation processes with high levels of uncertainty, short product life-cycles, and the costs of internal product development (Bellini et al., 2018). Laursen and Salter (2004) showed that firms seeking opportunities to collaborate with external partners such as suppliers, customers, or even competitors, may gain more from collaboration with academic institutions. Thus, a trend has arisen that has strongly stimulated the growth of university-industry collaboration (Morlacchi \& Martin, 2009), with technology firms increasingly absorbing and exploiting the results of academic research through collaborative university-industry relationships (UIRs) (Perkmann et al., 2013; Ankrah \& AlTabbaa, 2015; Kunttu \& Neuvo, 2018).

However, in addition to academic partners, industrial firms often involve their customers and end users of their products in product development (Gruner \& Homburg, 2000). This is particularly important for firms operating in business-to-consumer markets (B2C) with rapidly changing consumer trends, user expectations, and high competition. On the other hand, firms operating in industrial areas of business-to-business markets (B2B) are increasingly involving customer firms in their $\mathrm{R} \& \mathrm{D}$ processes in order to better understand customer needs and expectations. However, to achieve the desired results of innovative UIR collaborations, 


\title{
The Role of Academics, Users, and Customers in Industrial Product Development
}

\author{
Leena Kunttu, Yrjö Neuvo
}

firms must be able to commercialize the results of their innovative collaboration projects with external stakeholders, such as academics, users, or customers (Thursby \& Thursby, 2000).

The importance of commercializing the results of collaboration with university research has been recognized in many academic studies in this field (Siegel et al., 2004; Perkmann et al., 2013; Weckowska, 2015). Nevertheless, few studies have actually explored what kinds of practices can help facilitate commercialization in terms of organizational learning (Weckowska, 2015). In this study, the focus of the research lies in the involvement of users and customers in UIR collaborations.

Several studies have explored and highlighted the facilitating role of customer involvement in improving R\&D performance and innovation in high-technology firms (Gruner \& Homburg, 2000; Un et al., 2010). However, previous research has not studied what kinds of roles customers and users may play in the commercialization process of university-industry collaborations. This paper aims to address this gap, seeking to answer the following research question: What kinds of practices facilitate customer and user involvement in UIR collaboration? By seeking answers to this question, the study examines practices related to customer and user involvement in successful UIR commercialization processes, through a multiple case study of five UIR cases in Finland. Practices related to customer involvement were examined through inductive, qualitative research based on interviews, which was useful in this context for analyzing

organizational practices related to stakeholder collaboration.

\section{Background}

Acquiring and absorbing new state-of-the-art knowledge for a new product development process is a central challenge for firms operating in high-technology areas. To stay ahead of their competitors in terms of innovation performance and product development outcomes, the firms must search for knowledge outside (Asakawa et al., 2010). Thus, collaboration with a network of different external partners and stakeholders has become crucial, and firms are actively exploring opportunities for collaborative relationships with external partners (Emden et al., 2006). In research collaborations carried out in UIRs (Perkmann et al., 2013; Ankrah \& AL-tabbaa, 2015), industrial actors share and jointly develop new knowledge with university partners (Kunttu, 2017; Kunttu \& Neuvo, 2018). Academic involvement in UIR collaboration typically contributes to the early stages of industrial firms' product development processes (Gruner \& Homburg, 2000), as presented in Figure 1. This is because academic involvement in industrial projects often generates new ideas. Nevertheless, the commercialization of UIR innovations has traditionally been executed as an internal industrial process, not usually involving research partners.

On the other hand, industrial firms often involve their customers and end users in the final stages of product development, for example, in piloting or testing newly developed products or services (Gruner \& Homburg, 2000). In this manner, customer involvement in product

Industrial product development process

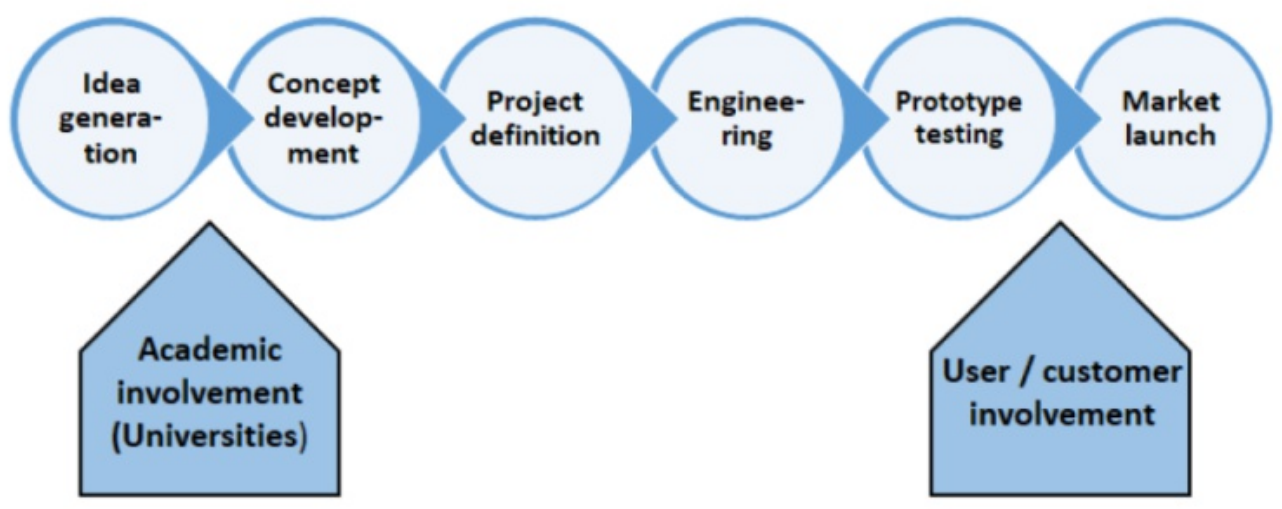

Figure 1. A traditional approach for stakeholder involvement in industrial firms' product development process. 


\section{The Role of Academics, Users, and Customers in Industrial Product Development} Leena Kunttu, Yrjö Neuvo

development usually focuses on the incremental improvement of current products, rather than on generating new ideas and possibilities for future products (Danneels, 2003 \& 2004; Un et al.a, 2010). Moreover, Gruner and Homburg (2000) have suggested that a firm's collaboration with customers best contributes to new product success when customers and users are involved in the later stages of the product development process, especially product testing activities - stages that are directly related to commercialization (Figure 1). However, as indicated by Gruner and Homburg (2000), customer involvement could also potentially contribute to the earliest stages of product development in terms of generating ideas, if this kind of interaction is correctly facilitated. The purpose of this paper is to investigate how customer and user interaction with industry could be combined with academic interaction taking place in UIRs, and how these two types of interaction could jointly contribute to industrial product development and commercialization.

University collaboration with industry typically contributes to the early stages of the process whereas the main focus of customer involvement lies in the final stages. This paper analyzes the role of user and customer involvement in UIR collaboration and, in particular, their impact on the commercialization process of collaboration outcomes. Since customer relationships can be seen in two distinct ways: relationships with $\mathrm{B} 2 \mathrm{~B}$ customers and direct relationships to end-users (B2C), these customer relationship types are being analyzed separately. The first group of relationships with customers, includes the firms who are an industrial partner's B2B customers. Involving customers in $\mathrm{R} \& \mathrm{D}$ collaboration (Cohen et al., 2002) helps collaboration partners to understand customer preferences and needs, which in turn contributes to the joint innovation process between collaboration partners (Un et al., 2010). The second stakeholder group are the end-users of an industrial firm's products, representing the consumers that may provide collaboration partners with valuable, experience-based knowledge using products. Understanding end-user expectations, needs, and favors is essential for companies that provide products and services for consumers.

\section{Methodology}

To explore what kinds of organizational practices may facilitate the involvement of customers and users in successful university-industry collaboration, and in this manner enable commercialization of collaboration results, a comparative, qualitative case study was conducted. The main case data collection method was interviews, but additional secondary data such as corporate brochures and archives, Internet information, and partnership descriptions were also used. The case studies were selected in a purposive manner to find longterm and close collaborative UIRs that had yielded successful results in terms of commercialized results from the collaboration. In addition, in all the selected cases, the customers or users were involved with the industrial partner in the UIR collaboration.

For the interviews, we designed and used a semistructured template. The template focused on the commercialization process by asking interviewees to tell about the process that yielded successfully commercialized innovations in their UIRs. Special focus of the interviews involved industrial firms' customers in the UIR. The interviewed industrial managers named their key collaborators on the university side, who were usually leaders of research groups. This way, the most appropriate people for the selected case study were involved, such that all the respondents were key persons in cases representing the selected UIRs. Interviews were recorded and transcribed. To maintain confidentiality of interview data, the analysis presented in this paper identifies interviewees only by position.

This paper has five cases, as summarized in Table 1 . Cases A, B, and C represent situations in which industrial firms collaborated with universities. This collaboration had a clear and significant involvement of the firms' users (B2C). In cases D, E, and F, the UIR collaboration involved firms' customers (B2B). In addition, case $\mathrm{C}$ also involved the firm's customers.

\section{Case descriptions}

In case A, a technology firm developing software for mobile devices had close collaboration with its university partner in the area of algorithm development. User experience is a very important aspect in the firm's final products, so it decided to include a user experience analysis on the scope of the joint development project. In practice, this meant that the university partner made user experience testing for new technologies that they were jointly developing. According to the firm's representatives, this kind of joint activity brought clear additional value to the project results, and also lowered the threshold to commercialize the results of the joint development activities. 


\section{The Role of Academics, Users, and Customers in Industrial Product Development} Leena Kunttu, Yrjö Neuvo

Table 1. A summary of case descriptions for the studied UIRs involving users or customers

\begin{tabular}{|c|c|c|c|c|c|c|}
\hline & Case A & Case B & Case C & Case D & Case E & Case $F$ \\
\hline Industrial area & $\begin{array}{l}\text { Mobile } \\
\text { devices }\end{array}$ & $\begin{array}{l}\text { Telecommuni } \\
\text { cations }\end{array}$ & $\begin{array}{l}\text { Heating } \\
\text { systems }\end{array}$ & $\begin{array}{l}\text { IT systems } \\
\text { for logistics }\end{array}$ & $\begin{array}{l}\text { Machinery for } \\
\text { construction } \\
\text { and mining }\end{array}$ & $\begin{array}{c}\text { Electrical } \\
\text { equipment } \\
\text { and systems }\end{array}$ \\
\hline $\begin{array}{l}\text { Relationship } \\
\text { age }\end{array}$ & Five years & Three years & Six years & Four years & Six years & Four years \\
\hline $\begin{array}{l}\text { Area of the } \\
\text { joint R\&D } \\
\text { projects }\end{array}$ & $\begin{array}{l}\text { Software } \\
\text { and } \\
\text { algorithms }\end{array}$ & $\begin{array}{l}\text { Service } \\
\text { products }\end{array}$ & $\begin{array}{l}\text { Service } \\
\text { products }\end{array}$ & $\begin{array}{l}\text { Smart } \\
\text { services for } \\
\text { logistics }\end{array}$ & $\begin{array}{l}\text { Service } \\
\text { products }\end{array}$ & $\begin{array}{l}\text { Service } \\
\text { products }\end{array}$ \\
\hline $\begin{array}{l}\text { Stakeholder } \\
\text { group } \\
\text { involved in } \\
\text { collaboration }\end{array}$ & Users & Users & $\begin{array}{l}\text { Users and } \\
\text { customers }\end{array}$ & Customers & Customers & Customers \\
\hline $\begin{array}{l}\text { Participants } \\
\text { of case } \\
\text { interview } \\
\text { (industry) }\end{array}$ & $\begin{array}{l}\text { Research } \\
\text { Manager }\end{array}$ & $\begin{array}{l}\text { Development } \\
\text { director }\end{array}$ & $\begin{array}{c}\text { R\&D } \\
\text { Director }\end{array}$ & $\begin{array}{l}\text { Global } \\
\text { program } \\
\text { manager } \\
\text { (R\&D) }\end{array}$ & R\&D Director & $\begin{array}{l}\text { Head of } \\
\text { R\&D unit }\end{array}$ \\
\hline
\end{tabular}

In case $\mathrm{B}$, a technology firm operating in the area of telecommunications collaborated with its university partner to develop new services to its users. In this kind of service product development, the role of user experience is essential, and for this reason, the collection and analysis of user experience data of the new services was an important part of collaboration.

Case $\mathrm{C}$ also presented a UIR collaboration case in which the partners jointly developed new service products for the firm's end users. For this, the collection and analysis of end user expectations and needs were examined at the beginning of the project, and also at a later stage when the developed services were introduced to the users. In this case, the collaboration also involved an analysis of the development of the firm's B2B partners, including retailers and service partners.

In case $\mathrm{D}$, the company involved some of its key customers in pilot $\mathrm{R} \& \mathrm{D}$ projects, which relied on longterm research collaboration with a university partner. In this collaboration, pilot customers tested, and the results of the research were verified under real market circumstances.

In a similar manner, case E presents a UIR in which an industrial firm's key customer was involved to test and give development feedback on the innovative solutions developed in the UIR.

In case F, the firm's key customers were involved in a practical research project carried out with the university in terms of a commercial pilot.

\section{Results}

Analysis of the case interviews and secondary data revealed a number of practices for commercializing UIR collaboration results. This section discusses the most prevalent practices for commercialization categorizes based on three central facilitators of collaboration: industrial partners' customer relationships, academic knowledge, and university student work.

Utilizing an industrial partner's relationships to its customers and users in UIRs

Involving customers and users in new product development has been shown to have a clear positive impact on new product success, especially in the final stages of the product development process (Gruner \& Homburg, 2000). For this reason, it may be beneficial for 


\section{The Role of Academics, Users, and Customers in Industrial Product Development}

Leena Kunttu, Yrjö Neuvo

industrial firms to involve their customers and users in the collaborative research process with their university partners (Un et al., 2010), who typically contribute to the early stages of product development (Markman et al., 2008). The role of user involvement in UIR collaboration was analysed in cases A, B, and C, whereas cases C, D, E, and $\mathrm{F}$ represent customer involvement in UIR research. In all cases, the collaboration between the firm and university were developed around a specific product or service development task. The involvement of users or customers was selected for a key research area in a joint project. The interviewees in cases considering end-user involvement (A-C) described this in the following manner:

Our research collaboration started some years ago as a joint research project that contributes to our consumer product development. However, quite soon we understood that it is important for the research project to collect field data from end-users to understand how the users really use our products (IND, A).

In our business area, the role of consumer experience is very important. Therefore, it was really good that we could use the consumer data analysis as an input in our university collaboration project that was related to service development (IND, B).

Thus, the interview data reveals that firms making research collaboration with universities in the area of consumer products see it as important to use end-user information as input in joint development work. The university researchers also had a very positive attitude towards this kind of collaboration, but pointed out that the consumer information could be utilized even more in UIR collaboration, since analysing user data also provides researchers with topics for developing scientific outcomes from the collaboration:
I feel that consumer and customer involvement fits very well to the scope of our joint development projects with industry. Our industrial partner has been very satisfied with the results of this kind of collaboration, and we as a research institute have been able to utilize the data collected from users (UNIV, C).
Publishing research results is often difficult in industrial research projects. However, user experience aspects in these projects are usually not so sensitive to industrial partners, who often allow

\author{
us to publish the results related to consumer \\ behavior (UNIV, B).
}

According to the interviews, the cases related to user involvement in research collaboration projects (A-C) focused on both ends of the product development projects:

In our collaboration, we were able to obtain valuable end-user information regarding the usage of our current products, as well as ideas for new features to be developed for future products (IND, A).

Consumer data collected in the project contributed both to the creation and conception of new services as well as improving our current services (IND, B).

In the surveys executed in our university collaboration projects, we collected user data concerning both feedback on our current products, and also obtained ideas for new services to be developed (IND, C)

Thus, the interview data indicates that when users are involved in UIR collaboration, a project may focus on both early stages (idea generation and concepting) and late stages (consumer testing and market launch) of the product development process. The interviewees in cases A-C had quite coherent opinions that this is a clear benefit compared to traditional UIR research projects that typically involve only early stages in the process:

When the users are involved in university collaboration, we definitely obtain more concrete research results, which contribute directly to our consumer products (IND, A).

Consumer data was crucial input for our joint development work with university (IND, A).

In cases representing customer involvement $(\mathrm{C}, \mathrm{D}, \mathrm{E}$, and $\mathrm{F}$ ), the industrial partners involved some of their key customers in research collaboration. The main motivation for industrial partners in this kind of collaboration was to enable smooth commercialization of technologies they were developing with universities:

Co-creation with our pilot customers is quite active in our own $R \& D$. We have also a long tradition of making research collaboration with universities. In some projects, we have been able to combine these two things, which really helps us to implement the results of research collaboration and test them with 


\section{The Role of Academics, Users, and Customers in Industrial Product Development}

\section{Leena Kunttu, Yrjö Neuvo}

pilot customers (IND, D).

We have developed a new technological solution in our joint research project with our university partner. Now, one of our large customers has been involved in this project, and it will test the prototype in its real working environment. Our university partner also collects information on this testing and uses it for further development work (IND, E)

\section{Making a commercial pilot with one of our key customers clearly helps us to reach valuable results in the current collaboration project with the university (IND, F)}

The interviews in cases $\mathrm{D}, \mathrm{E}$, and $\mathrm{F}$ reveal that industrial firms may facilitate the commercialization of university collaboration research results by adopting their customers to the final phases of the development process (Gruner \& Homburg, 2000). When these "lead customers" test the prototypes together with the firm's $\mathrm{R} \& \mathrm{D}$ and university researchers in real circumstances, researchers and industrial developers may collect valuable data and feedback on product usage. This, in turn, helps the collaborating partners to take steps for further development:

\section{For us, our university partner contributed our service development work by facilitating interaction with our key customer firms, for example, by interviewing customer representatives. This steered the development work a lot (IND, C)}

Thus, the interview data from our study indicates that involving customer firms in university collaboration helps facilitate the commercialization of joint development work by means of prototype testing and product validation. This finding is in line with the conclusions of Gruner and Homburg (2000), who indicated that customers' contribution focuses on the later stages of product development. However, the interview data also showed that customer involvement has in many cases also impact on the early phases of the process (idea generation):

The customer firms have ideas that are related to the improvement of the products by means of new features and properties. The customer interviews made by the university partner helped us to collect and systematically utilize these inputs (IND, C)

\section{Sometimes our pilot customers have innovative}

\begin{abstract}
ideas that may initiate new $R \& D$ projects. These projects are typically carried out together with this customer and our university partner (IND, E)
\end{abstract}

Combining academic knowledge with customer input

One of the researchers' key interest areas in the interviews was to understand industrial firms' motives to involve their users and customers in research collaboration with universities. The industrial interviewees agreed that the main benefits for them lies in academic competences and scientific knowledge that can be complemented with user and customer experience knowledge that most university partners also possess:

When we decided to involve the user experience aspects to our research project with the university scientists, the project team was extended with new researchers who were concentrating on consumer experience. They carried out the user studies related to our project, and we could utilize the results in the project (IND, A).

In our research project, we have utilized data collected from both users and customers. In both cases, the university researchers have been in a key role, since they have had both scientific understanding, and practical skills to make surveys and interviews of our users and customers. They have also analyzed the results and have made good suggestions how to use them in our product and service development (IND, C).

Thus, the interviews highlight the importance of multidisciplinary capabilities of university research teams: the university partner should be able to provide the industrial collaborator with both technological knowledge, and understanding of user or customer relations. For this reason, the universities have utilized multi-disciplinary teams in their industrial projects:

In our research team, the main competence area is technology development. However, we have seen it beneficial to extend our teams with people having backgrounds from marketing, consumer interaction, or psychology. This way, we can provide our industrial partner an optimal combination of competences for both technological and user experience understanding (UNIV, B).

I have seen in many previous industrial projects that 


\section{The Role of Academics, Users, and Customers in Industrial Product Development}

Leena Kunttu, Yrjö Neuvo

\begin{tabular}{|c|c|c|}
\hline Category: & $\begin{array}{l}\text { User Involvement } \\
\text { (Cases } A, B, C)\end{array}$ & $\begin{array}{l}\text { Customer involvement } \\
\qquad \text { (Cases } C, D, E, F)\end{array}$ \\
\hline $\begin{array}{l}\text { 1) Utilizing the } \\
\text { industrial partner's }\end{array}$ & $\begin{array}{l}\text { - Collecting and utilizing } \\
\text { data on the end-user } \\
\text { experience within UIR } \\
\text { collaboration projects }\end{array}$ & $\begin{array}{l}\text { - Collecting and utilizing data } \\
\text { on the customer experience } \\
\text { within UIR collaboration } \\
\text { projects }\end{array}$ \\
\hline $\begin{array}{l}\text { user/customer } \\
\text { relationships in UIRs }\end{array}$ & $\begin{array}{l}\text { - Analyzing consumer } \\
\text { behavior aspects in terms of } \\
\text { surveys or interviews }\end{array}$ & $\begin{array}{l}\text { - Collecting and analysing the } \\
\text { data from joint development } \\
\text { work carried out between a } \\
\text { firm and its pilot customers }\end{array}$ \\
\hline $\begin{array}{l}\text { 2) Combining } \\
\text { academic knowledge } \\
\text { with customer/user } \\
\text { inputs }\end{array}$ & $\begin{array}{l}\text {-Involving a UIR project } \\
\text { with user experience } \\
\text { experts having backgrounds } \\
\text { in marketing, psychology, or } \\
\text { management }\end{array}$ & $\begin{array}{l}\text {-Involving multi-disciplinary } \\
\text { research teams } \\
\text { - Utilizing inputs from the } \\
\text { sales department }\end{array}$ \\
\hline $\begin{array}{l}\text { 3) Employing } \\
\text { students and } \\
\text { university research } \\
\text { staff in customer } \\
\text { interface }\end{array}$ & $\begin{array}{l}\text {-Employing university } \\
\text { students in field data } \\
\text { collection } \\
\text {-Utilizing a student's } \\
\text { understanding of consumer } \\
\text { behavior }\end{array}$ & $\begin{array}{l}\text {-Employing university } \\
\text { students in the collection of } \\
\text { customer inputs via } \\
\text { interviews }\end{array}$ \\
\hline
\end{tabular}

Table 2. A summary of collaborative practices identified in this paper

pure technological understanding is not enough. For this reason, we have gained competences, for example, for marketing and management in our research team (UNIV, C).

While utilizing multi-disciplinary university research teams in collaboration is important, it is also crucial that industrial partners involve cross-organizational teams in UIR collaboration:

We found it important to involve also our marketing people and people responsible for customer relationships in this collaboration. They know the customers best, and they can help the researchers to make contacts with customers. It is also very beneficial to analyze the results of customer studies with them (IND, C).
Involving pilot customers in joint research projects means that we involve also our sales department in the project. This way, the university researchers get inputs from both customer, sales, and R\&D. I think that this is really beneficial (IND, D).

Employing students and university research staff in the customer interface

Experiences involving university students in research collaboration between industry and academia in terms of innovation and idea generation have been promising (Kunttu, 2017). In all the cases analyzed in this paper, students have been somehow involved in the joint research project between university, industrial firm, and its customers or end-users. The interviewed industrial managers underlined the role of students in the project, particularly in collecting field data from product users 


\title{
The Role of Academics, Users, and Customers in Industrial Product Development
}

\author{
Leena Kunttu, Yrjö Neuvo
}

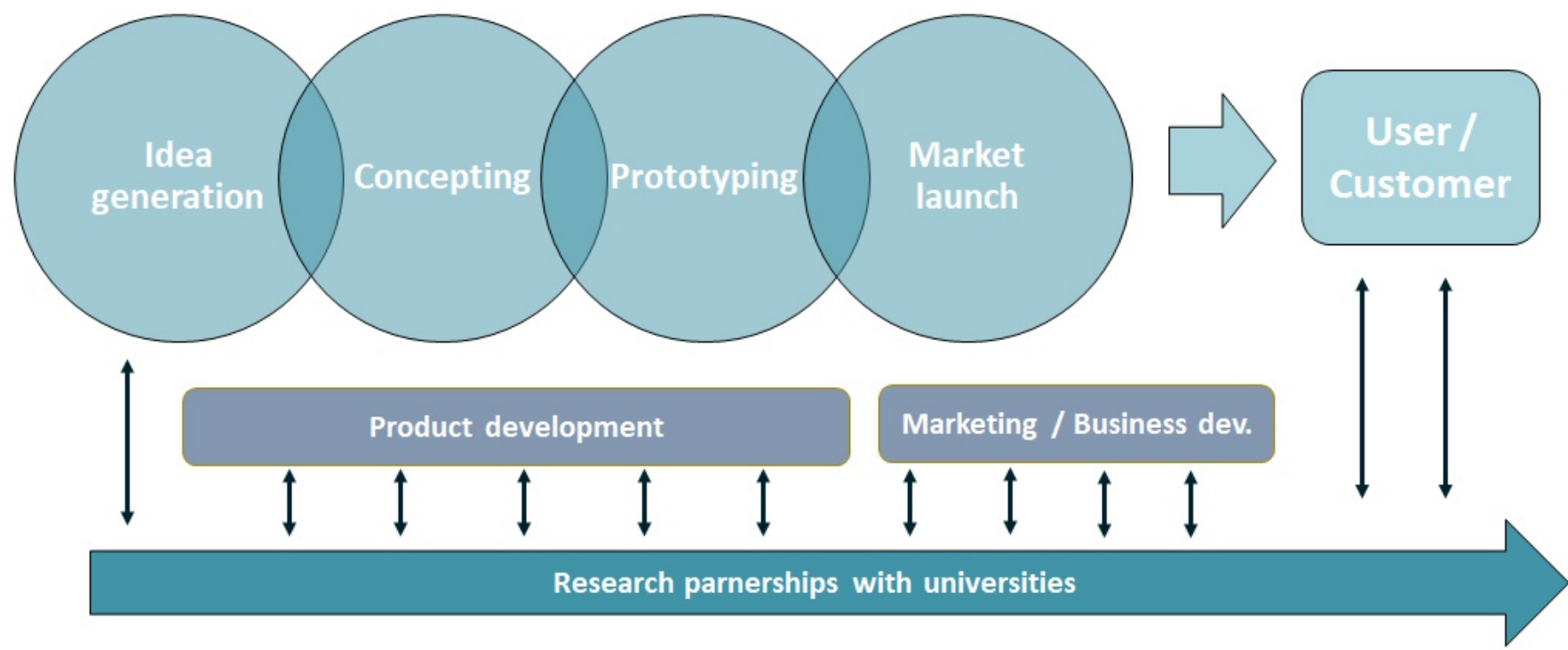

Figure 2. A model of the academic involvement in university-industry collaboration.

(Cases A-C):

In our joint project with a university partner, the university students made an excellent job when they collected field data from our product users. This way, we were able to get very valuable information on the users' opinions related to the real usage of our products, and in particular to the new features that we were developing (IND, $A$ ).

The university partner provided us an opportunity to use student groups to make user studies as a part of our larger collaboration project. The groups collected information from our current users and also potential new users, and we really learned a lot about user experience and expectations related to our services. I feel that these findings were one of the key results of the whole collaboration (IND, B).

The user studies carried out in different phases of our research project with university really steered the project targets and scope in the right direction. At the end of the project, the user feedback collected by the students really helped us to understand the potential of the service products that we had developed (IND, C).

Again, the interviewees in cases A-C felt it valuable that when working in user interface the students collected data at both early and late stages of the product development process, which confirms our earlier indication about contributing both to the product development cycle. The students were involved in customer involvement in case $\mathrm{C}$, whereas in cases $\mathrm{D}$ and $\mathrm{E}$, the students and university research staff were mostly involved in customer interaction:

The students made valuable work in interviewing the customers along with university researchers (IND, C).

The university partners also appreciated the students' contribution in the research collaboration:

I have employed student groups in several industrial research projects. In my experience, one of the most fruitful ways of working for students is to operate in the end-user interface. This is probably due to the fact that the students can easily take the position of a consumer, and they can also collect consumer information easily from their networks (UNIV, B).

Students are eager to contribute to the industrial projects and they are pretty good in making consumer interviews, surveys, and other data collection from the field (UNIV, A).

Academics should be involved in the whole productization chain beginning from idea generation to customer and user involvement. This requires academic 


\section{The Role of Academics, Users, and Customers in Industrial Product Development} Leena Kunttu, Yrjö Neuvo

skills and competences to collaborate with a variety of different stakeholders.

\section{Conclusion}

The goal of this paper was to investigate user and customer involvement practices in UIR collaboration, and in particular, to understand the collaborative practices by which users and customers may be involved in UIR collaboration. The key practices recognized in this paper are summarized in Table 2.

The main findings of the paper are as follows. First, an analysis of six UIR cases showed that involving users and customers in joint research efforts between universities and their industrial partners clearly helps the partners to commercialize the results of their research collaboration. Involving users and customers in UIR collaboration helps companies and universities to extend the focus of joint research also to later stages, which are directly related to commercialization, as summarized in Figure 2. For this reason, university research staff should nowadays acquire skills and competences to collaborate with a variety of stakeholders. These stakeholders are not only users and customers, but also industrial partners' marketing and business development organizations, who are mainly responsible for commercializing new products and services. Second, user and customer feedback, opinions, and experiences represent very important inputs to product development and new product success. In this sense, they are also valuable inputs for practicaloriented UIR research projects.

The interview data showed that involving user and customer inputs with academic research capabilities brings clear benefits to UIR projects, thanks to the multi-disciplinary capabilities of university research teams, which can combine scientific knowledge with understanding of user behaviours and customer relations. Third, user and customer involvement fit well with university-industry collaboration. This is because universities have good capabilities to interact and communicate with users and customer firms, collect consumer data, and make different kinds of user or consumer studies as a part of their research. The interviewed industrial managers appreciated this, and agreed that this kind of interaction clearly adds value for UIR research collaboration between the firms and universities. The interviews also emphasized the value of university students in collecting and analysing consumer and customer data.

\section{References}

Ankrah, S. and Al-tabbaa, O. 2015. Universities industry collaboration\%: A systematic review. Scandinavian Journal of Management. Elsevier Ltd, 31(3): 387-408.

doi: 10.1016/j.scaman.2015.02.003

Ankrah, S. and AL-Tabbaa, O. 2015. Universitiesindustry collaboration: A systematic review. Scandinavian Journal of Management. Elsevier Ltd, 31(3): 387-408.

doi: 10.1016/j.scaman.2015.02.003

Asakawa, K., Nakamura, H. and Sawada, N. 2010. Firms' open innovation policies, laboratories' external collaborations, and laboratories' R\&D performance. $R \& D$ Management, 40(2): 109-123.

doi: $10.1111 /$ j.1467-9310.2010.00598.x

Bellini, E., Piroli, G. and Pennacchio, L. 2018. Collaborative know-how and trust in university-industry collaborations: empirical evidence from ICT firms. Journal of Technology Transfer. Springer: 1-25.

doi: 10.1007/s10961-018-9655-7

Chesbrough, H. W. 2003. The Era of Open Innovation. MIT Sloan Management Review: 35-42. doi: 10.1371/journal.pone.0015090

Cohen, W. M., Nelson, R. R. and Walsh, J. P. 2002. Links and impacts\%: The influence of public research on industrial R \& D. Management Science, 48(1): 1-23.

Danneels, E. 2003. Tight-loose coupling with customers: The enactment of customer orientation. Strategic Management Journal, 24(6): 559-576. doi: $10.1002 / \mathrm{smj} .319$.

Danneels, E. 2004. Disruptive Technology Reconsidered: A Crtique and Research Agenda. Journal of Product Innovation Management, 21(1): 246-258.

Emden, Z., Calantone, R. J. and Droge, C. 2006. Collaborating for new product development: Selecting the partner with maximum potential to create value. Journal of Product Innovation Management, 23(4): 330-341.

doi: 10.1111/j.1540-5885.2006.00205.x

Enkel, E., Gassmann, O. and Chesbrough, H. 2009. Open $\mathrm{R} \& \mathrm{D}$ and open innovation: exploring the phenomenon. R\&D Management, 39(4): 311-316. doi: $10.1111 /$ j.1467-9310.2009.00570.x

Gruner, K. E. and Homburg, C. 2000. Does customer interaction enhance new product success?, Journal of Business Research, 49(1): 1-14.

doi: 10.1016/S0148-2963(99)00013-2

Kunttu, L. 2017. Educational Involvement in Innovative University - Industry Collaboration. Technology Innovation Management Review, 7(12): 14-23.

Kunttu, L. and Neuvo, Y. 2018. Balancing learning and knowledge protection in university-industry collaborations. The Learning Organization.

doi: 10.1108/TLO-06-2018-0103 


\title{
The Role of Academics, Users, and Customers in Industrial Product Development
}

\author{
Leena Kunttu, Yrjö Neuvo
}

Morlacchi, P. and Martin, B. R. 2009. Emerging challenges for science, technology and innovation policy research: A reflexive overview. Research Policy, 38(4): 571-582.

doi: $10.1016 /$ j.respol.2009.01.021

Perkmann, M. et al. 2013. Academic engagement and commercialisation: A review of the literature on university-industry relations. Research Policy. Elsevier B.V., 42(2): 423-442.

doi: 10.1016/j.respol.2012.09.007

Siegel, D. S. et al. 2004. Toward a model of the effective transfer of scientific knowledge from academicians to practitioners: Qualitative evidence from the commercialization of university technologies. Journal of Engineering and Technology Management - JET-M, 21(1-2): 115-142.

doi: 10.1016/j.jengtecman.2003.12.006

Thursby, J. G. and Thursby, M. C. 2000. Who is selling the iwory tower? Sources of growth in university licensing. Management Science, 48: 90-104.

Un, C. A., Cuervo-Cazurra, A. and Asakawa, K. 2010. R\&D Collaborations and Product Innovation. Journal of Product Innovation Management, 27(5): 673-689. doi: 10.1111/j.1540-5885.2010.00744.X

Weckowska, D. M. 2015. Learning in university technology transfer offices: Transactions-focused and relations-focused approaches to commercialization of academic research. Technovation. Elsevier, 41: 62-74. doi: 10.1016/j.technovation.2014.11.003

West, J. et al. 2014. Open innovation\%: The next decade. Research Policy. Elsevier B.V., 43(5): 805-811. doi: 10.1016/j.respol.2014.03.001

Citation: Kunttu, L., Neuvo, Y. 2020. The Role of Academics, Users, and Customers in Industrial Product Development. Technology Innovation Management Review, 10(3): 59-68.

http://doi.org/10.22215/timreview/1337

Keywords: University-industry collaboration, stakeholder involvement, user involvement, customer involvement, commercialization

\section{About the Authors}

Leena Kunttu holds a PhD degree in Information Technology (signal processing) from the Tampere University of Technology, Finland (2006), a PhD degree in Economics (innovation management) from the University of Vaasa, Finland (2019), and Master of Arts degree in Education from the University of Tampere (2020). Between 2007 and 2012, she served as Senior Manager in an area of innovation at the Nokia Corporation. During her career in Nokia, she led a number of collaborative projects between the company and external research institutes, such as universities. She also led and participated in joint educational activities between Nokia and universities. Since 2015, Dr. Kunttu has served as a postdoc researcher in an area of innovation at the University of Vaasa. Her current research interests include university-industry collaboration, educational involvement and the commercialization of university technologies.

Yrjö Neuvo received his Ph. D, degree from Cornell University in 1974. He had a 19-year academic career as professor of Signal Processing at Tampere University of Technology, as National Research Professor at the Academy of Finland and as a visiting professor at University of California, Santa Barbara. He was Chief Technology Officer and member of the Group Executive Board at Nokia Corporation from 1993 to 2005. His responsibilities included managing R\&D activities for mobile phones. After retiring from Nokia he started his third career as Professor and Research Director at Aalto University, Finland. At Aalto, Yrjö has developed university wide programs for doctoral education fostering cross-disciplinary learning and industry-academia interplay. He has been Chairman of ARTEMIS JTI Governing Board $2007-2008$ and member of the Executive Committee of European Institute of Innovation and Technology (EIT) 2008 - 2012. He was General Chairman of the 1988 IEEE International Symposium on Circuits and Systems and of the IEEE International Conference on Communications (ICC 2001). He is Life Fellow of IEEE, Member of Academia Europaea, the Swedish Academy of Technical Sciences, two Finnish Academies and holds four honorary doctorates. Asteroid $1938 \mathrm{DN}$ carries his name Neuvo. 